Vol. XVI. No. 2.-Botanical Gazette.-FeB., 1891.

\title{
Notes on the apical growth in the roots of Osmunda and Botrychium.
}

\author{
DOUGLAS HOUGHTON CAMPBELL.
}

(WITH PLATE V.)

With the rapid advance in histological methods, it has now become possible to study with the utmost exactness the development of the most delicate plant tissues, and in consequence a new impulse has been given to the investigation of the histogeny of the higher plants, with a view to elucidating their affinities.

Naturally the Pteridophytes have been among the most frequently investigated forms, and my purpose here is to put in brief form the results of some observations on the growing points of the roots of Osmunda and Botrychium, which may serve to supplement the more extended researches of other authors on the ferns.

Of the genus Osmunda, O. regalis has been exhaustively studied by Bower ${ }^{1}$, but our other native species, O. cinnamomea, and especially O. Claytoniana are, so far as their histology is concerned, almost unknown.

These species, therefore, were chosen for the examination of the roots. Of the genus Botrychium, B. ternatum, and B. Virginianum were used.

The roots were fixed with a 1 per cent aqueous solution of chromic acid, or in some cases with Flemming's chrom-osmicacetic-acid mixture, but the former was found to give the best results. After thoroughly washing, to remove all traces of the acid, and then dehydrating, the specimens were brought gradually through turpentine and then imbedded in paraffin and sectioned on a Minot microtome. Various stains were tried, but by far the most satísfactory was a solution of Bismarck-brown in 70 per cent. alcohol. The specimens were stained on the slide with this mixture, which stains the young cell-walls strongly, and renders the study of the earlier celldivisions an easy matter.

${ }^{1}$ Bower: The comparative examination of the meristems of ferns as a phylogenetic study. Annals of Botany, vol. iii, no. 9, Aug. 1889. 
OSMUNDACEÆ. - The Osmundaceæ differ in several respects from the true leptosporangiate ferns, seeming to connect the latter, to a certain extent, with the Marattiaceæ, and perhaps with the Ophioglossex. An examination of sections of the root-tips shows that the almost mathematical regularity that prevails in the segmentation of the apical cell of the Leptosporangiatæ and Equisetum is here very much less evident. Bower ${ }^{1}$ states that in O. regalis there may be a single apical cell of the same form as in the leptosporangiate ferns, but that it never shows the same regularity in its segmentation, and that it may be replaced by two or three initial cells, or a single four-sided pyramidal initial. In Todea barbara² (also one of the Osmundaceæ) he found usually four similar initial cells, and in no case a single one, although Van Tieghem and Douliot $^{3}$ ascribe to this species a single apical cell of the ordinary fern-type.

Of the two species investigated by me, O. cinnamomea approached, on the whole, more nearly the forms described and figured by Bower; O. Claytoniana resembled more the ordinary fern-type in the regularity of the segmentation of the apical cell, although this seems to be regularly a four-sided pyramid, instead of three-sided as in the other true ferns.

Osmunda cinnamomea. - This species seems to correspond in many respects with $O$. regalis. The roots are stout, and sections, either transverse or longitudinal, show the cells at the growing-point to be very large, with correspondingly large nuclei, but relatively little protoplasm. In all specimens examined, there appeared to be a single initial cell, but owing to the large size of the young segments, it was not always easy to determine positively that this was the case; but a careful examination of the sections led to the conclusion that all the cells were traceable to a single apical cell.

The apical cell, seen in profile, is more or less regularly triangular (fig. 1), but may be truncate at the base. In all the transverse sections examined, this cell appeared nearly square, so that the normal form of the apical cell in this species appears to be a four-sided pyramid. In transverse sec-

${ }^{1}$ L. c., p. 310.

2L. c., p. 314.

${ }^{3}$ Van Tieghem et Douliot: L'Origine des Radicelles, Ann. des. Sci. Nat. (Bot.) 1888, vol. viii, pp. 378-380. These authors state that all the Osmundaceæ examined by them have a single apical cell, essentially like that of the other ferns,
but their accounts are very brief. 
tions (figs. 2, 3), the adjacent cells are sometimes of nearly the same size and shape as the apical cell; but this position generally shows plainly that they are derived from it, and the relation of the young segments to the apical cell may be readily made out (fig. 2 ). It is, of course, not impossible that here, as in Todea, there may be sometimes four initial cells, but this view is not supported by my own observations.

Owing to the slowness of cell-division in the young segments, and the comparative irregularity of the same, it is difficult to trace the limits of the segments beyond the youngest ones.

The apical cell, as in O. regalis, is deeper than in most Filicinex, but from its faces the segments are cut off much as in the latter. The segments usually form a spiral, although cases were met with that looked as if this were not the case, but that they arose in pairs from opposite sides of the foursided initial-cell. From the outer face segments are also cut off, and these contribute to the growth of the root-cap, but this is also formed in part from cells cut off from the young lateral segments (fig. 1).

While the earlier divisions of the young segments do not follow any absolute rule, nevertheless they correspond in the main to those observed in the other Filices. The first wall in the young segment usually divides it radially into two cells, one of which is deeper than the other, as the wall does not exactly bisect the segment. This is followed in each semisegment by a transverse wall that separates an inner small cell from an outer larger one. The former, as in the other ferns, probably gives rise only to the plerome-cylinder; the latter to periblem and dermatogen, and in part also to the root-cap (fig. 1). As the root-cap is derived both from the outer segments of the apical cell and the outer cells of the lateral segments, its inner layers lack that regularity that is so marked in most ferns; but as the cells enlarge this irregularity is in great part lost, and the outer layers of cells show a stratified appearance, nearly as regular as in the other Filices.

The plerome cylinder is in this species especially large, somewhat oval in section, but with poorly defined limits, so that it is not possible to state positively whether or not it owes its origin exclusively to the innermost cells of the segments. Occupying the center are several very wide cells that early cease to divide and are very conspicuous. These are 
the young tracheæ, and in this species are especially noticeable (fig. 1, tr).

Osmunda Claytoniana. - On comparing the roots of this species with the foregoing, we are struck first by their smaller size; and on examining the growing-point, the cells show a corresponding decrease in size, as well as greater regularity in the divisions of the apical cell and its segments. As in O. cinnamomea, the apical cell appears in vertical section deeply triangular, or occasionally truncate below. In one cise (fig. 5), which closely resembles Bower's figures, 10 and $14^{1}$, two cells of very similar appearance occupied the growing point, but the smaller of these two, $x^{\prime}$, was probably a segment of the larger one, $x$, which is to be regarded as the real apical cell. In transverse sections, a single, foursided cell was met with in nearly every case, and from its position, and that of the surrounding cells, was unmistakably the single initial cell. It is usually quite regularly oblong, and the divisions of the segments show a very considerable degree of regularity. In no case was a regular three-sided apical cell met with, although in one section (fig. 7) it was nearly of this form; but an examination of the adjacent segments showed that this was in all probability only temporary, as the youngest set of segments formed a nearly perfect rectangle, and the three-sided form of the apical cell apparently arose from the walls cutting off segments on opposite sides of the cell deviating so far from their normally parallel direction as to intersect.

Sometimes the arrangement of the cells seen in longitudinal section is almost as regular as in the Polypodiaceæ or Equisetum (fig. 4), and in such cases the limits of the segments are traceable for a long time; and in transverse sections this is also evident for the first complete set of segments (fig. 6). From a study of both, the successive divisions in the young segments may be plainly determined. While not as diagramatically regular as in the true leptosporangiate ferns, nevertheless the divisions are much more definite than in either $\mathrm{O}$. regalis or $\mathrm{O}$. cinnamomea, and except for the irregularity in the formation of the root-cap, correspond very closely to the regular fern-type. The primary tissue-systems are better differentiated, and the plerome-cylinder may be traced back with certainty, at least in such regular forms as 
that shown in fig. 4 , to the inner of the two primary cells into which each semi-segment is divided. ${ }^{1}$ (fig. $4, p$. c.). The plerome-cylinder is much smaller than in $\mathrm{O}$. cinnamomea, and in its mature condition resembles very closely the bundle of the ordinary fern-root, and differs from the investigated species of Osmunda and Todea ${ }^{2}$ in the better development of the bundle-sheath and in having the pericambium consisting of but one, or at most two layers. The arrangement of the tracheary tissue, too, is entirely similar to that of the Polypodiaceæ.

OPHIOGLOSSE Æ. - Unfortunately at the time these investigations were made, only a very small number of plants of Ophioglossum were obtainable, and the roots of these were not properly prepared for imbedding, the plants having been preserved in ordinary alcohol, so that it was impossible to get satisfactory preparations, and my observations were therefore confined to the two common Botrychia, B. ternatum and B. Virginianum.

The Ophioglosseæ have been comparatively little-studied, ${ }^{3}$ and the investigations that have been made on the roots are not satisfactory. B. ternatum was examined by me some time since, ${ }^{4}$ and the results of the paper then published were confirmed for the most part; but somewhat less regularity in the segmentation of the apical cell was found to exist than there described, and a consequent departure from the ordinary fern-type.

Botrychium ternatum. - The apical cell of this species (fig. 9) is in form quite like that of the Polypodiaceæ, but the segments are noticeably larger and remain longer undivided, in which respect they approach the Osmundaceæ. The first division in the young segment (fig. 10) follows the regular rule, dividing it lengthwise into two cells, which are, however, more unequal than is usually the case in ferns, and the subsequent divisions are less definite, although they follow the same general rule. Here, as in the Osmundacer, the

1 Van Tieghem and Douliot call attention to the fact, confirmed by the observations recorded here, that the Osmundaceæ differ from the other ferns in having the innermost of the two primary cells of the semi-segment smaller, and giving rise directly to the procambium. (1. c. p. 379.)

2 De Bary: Comp. Anat. (Eng. translation) p. 364.

${ }^{3}$ Holle: Ueber die Vegetationsorgane der Ophioglosseen; Bot. Zeit., 1875.

${ }^{4}$ Campbell: The development of the root of Botrychium ternatum; Bot. Gazette, March, 1886. 
plerome initial cell becomes separated before the division of the outer cells of the segment and the initials of the periblem and dermatogen. ${ }^{1}$ The cap segments, however, show much less regularity, and the stratification of the root-cap is soon entirely lost. Comparing, too, the apex of the root (exclusive of the root-cap) with that of most other ferns, it is found to be much more convex.

Botrychium Virginianum.-Comparing the root of B. Virginianum (fig. 11) with B. ternatum, while the structure on the whole is closely similar, the former species approaches more nearly the fern-type. Sometimes (fig. 12) the crosssection shows almost as perfect regularity as in the Polypodiacer, and this is evident, too, though to a less degree, in longitudinal sections. The root-tip is flatter than in B. ternatum, and the stratification of the root-cap more evident, although much less so than in the Filices.

CONCLUSIONS. - As a result of the foregoing statements, it appears that in the Osmundace there may be very considerable variations in the structure of the root-tip, and that of our native species, O. Claytoniana, on the whole, departs least from the ordinary fern-type, and may be looked upon as the most nearly related to the true Leptosporangiatæ. "

Of the two species of Botrychium, B. Virginianum approaches more nearly the Filices in the structure of its roots, as it does in other respects. " A further investigation of Ophioglossum and the simpler species of Botrychium will probably show in these a still further departure from the type than in B. ternatum.

Bloomington, Indiana, November, 1890.

\section{Explanation of Plate V.}

All magnified about 175 diameters. $x$, apical cell. $a, a$, the primary wall in the young segment. The boundaries of the younger segments are indicated by
the heavy lines.

Figs. 1-3. Osmunda cinnamomea. Fig. 1, longitudinal; 2 and 3 , transverse sections. $t r$, young tracheæ.

Figs. 4-8. O. Claytoniana. 4, 5, longitudinal; 6, 7, transverse sections. Fig. 8 is a transverse section a short distance below the apical cell. In fig. 5 the youngest segment $\left(x^{\prime}\right)$, closely resembles in form the true initial cell $(x)$.

${ }^{1}$ Van Tieghem and Douliot dispute the view that the epidermis of the root in any ferns is derived from the lateral segments at all, but claim that it originates from the outer segments, the same that form the root-cap.

? The conclusion given here, based upon the roots, is also confirmed by a study of the prothallium, which in several respects resembles the Polypodiacer more closely than does either $\mathrm{O}$. cinnamomea or $\mathrm{O}$. regalis.

${ }^{3}$ Campbell: On the affinities of the Filicineæ; Bot. Gazette, Jan., 1890, p. 5 . 
Figs. 9, 10. Botrychium ternatum. 9, longitudinal; 10, transverse section.

Figs. 11, 12. Similar sections of B. Virginianum. p. c., procambium cylinder.

Fig. 13. Transverse section of the root of B. ternatum just below the apical cell. The outlines of the first three segments are distinguishable.

\section{Two new plants from the Cascade Mountains.}

\section{B. L. ROBINSON.}

(WITH PLATE VI.)

In a small collection of phænogams from Mt. Rainier and vicinity, sent by Mr. C. V. Piper to the Gray Herbarium, two new species occur, which form the subject of the present paper. One of them is more or less closely related to Luina hypoleuca Benth. and Cacaliopsis Nardosmia Gray, and is of special interest, since it does not fall strictly within the limits of either genus as now described. Since, however, both of these genera are monotypic it seems highly injudicious to add a third genus to the group, intermediate between the two, and also of a single species. As will be seen from the description that follows, the new species resembles, on the whole, the older genus Luina more closely, the most important point in which it differs from it being the entire or subentire base of the anthers, in which respect it is more like Cacaliopsis. In its sessile entire leaves, few-flowered oblong heads with few rigid involucral scales, it accords with Luina. Its inflorescence is still more racemose than in Cacaliopsis, and, as in that genus, the upper bracts are adnate to the pedicels; in the entire absence of pubescence from stem and leaves, in the tawny pappus, and in some characters of the corolla it differs from both. While highly probable that Luina should be made to include Cacaliopsis, this point may well be left for future discoveries to decide. The characters of the new species are as follows:

Luina Piperi. (P1. VI, figs. 1-6).- Stem simple, virgate, striate, glabrous: cauline leaves oblong-lanceolate, shortly acuminate, narrowed to sessile base, entire, in the single type specimen green and glabrous on both sides; radical leaves unknown: inflorescence racemose, one foot long; pedicels 2-6 lines long, together with the involucral scales somewhat to- 


\section{$2 \mathrm{BHL}$ Biodiversity Heritage Library}

1891. "Notes on the Apical Growth in the Roots of Osmunda and Botrychium." Botanical gazette 16(2), 37-43. https://doi.org/10.1086/326615.

View This Item Online: $\underline{\text { https://www.biodiversitylibrary.org/item/38663 }}$

DOI: https://doi.org/10.1086/326615

Permalink: https://www.biodiversitylibrary.org/partpdf/222012

\section{Holding Institution}

Missouri Botanical Garden, Peter H. Raven Library

\section{Sponsored by}

Missouri Botanical Garden

\section{Copyright \& Reuse}

Copyright Status: Public domain. The BHL considers that this work is no longer under copyright protection.

This document was created from content at the Biodiversity Heritage Library, the world's largest open access digital library for biodiversity literature and archives. Visit BHL at https://www.biodiversitylibrary.org. 